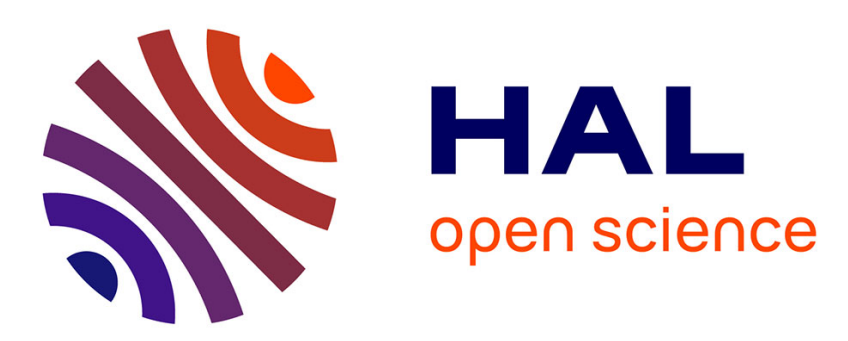

\title{
Influences of deposition and crystallization kinetics on the properties of silicon films deposited by low-pressure chemical vapour deposition from silane and disilane
}

Pierre Temple-Boyer, Bernard Rousset, Emmanuel Scheid

\section{- To cite this version:}

Pierre Temple-Boyer, Bernard Rousset, Emmanuel Scheid. Influences of deposition and crystallization kinetics on the properties of silicon films deposited by low-pressure chemical vapour deposition from silane and disilane. Thin Solid Films, 2010, 518 (23), pp.6897-6903. 10.1016/j.tsf.2010.07.037 . hal$01511365 \mathrm{v} 2$

\author{
HAL Id: hal-01511365 \\ https: / hal.laas.fr/hal-01511365v2
}

Submitted on 14 Apr 2018

HAL is a multi-disciplinary open access archive for the deposit and dissemination of scientific research documents, whether they are published or not. The documents may come from teaching and research institutions in France or abroad, or from public or private research centers.
L'archive ouverte pluridisciplinaire HAL, est destinée au dépôt et à la diffusion de documents scientifiques de niveau recherche, publiés ou non, émanant des établissements d'enseignement et de recherche français ou étrangers, des laboratoires publics ou privés. 


\title{
Influences of the deposition and crystallization kinetics on the properties of silicon films deposited by low-pressure chemical vapour deposition from silane and disilane
}

Pierre Temple-Boyer, B. Rousset, E. Scheid

\author{
CNRS-LAAS; 7 avenue du Colonel Roche, F-31077 Toulouse, France \\ Université de Toulouse; UPS, INSA, INP, ISAE; LAAS; F-31077 Toulouse, France \\ Tel: +33-5-6133-6954, Fax: +33-5-6133-6208, E-mail: temple@laas.fr
}

\begin{abstract}
:
The paper deals with the properties of silicon films obtained by low-pressure chemical vapour deposition (LPCVD). Two gaseous sources characterized by different deposition temperatures, i.e. disilane $\mathrm{Si}_{2} \mathrm{H}_{6}\left(420-520^{\circ} \mathrm{C}\right)$ and silane $\mathrm{SiH}_{4}\left(520-750^{\circ} \mathrm{C}\right)$, were studied in order to understand the influences of the deposition and crystallization kinetics on the silicon films properties. Thus, the deposition of amorphous, semi-crystallized and polycrystalline silicon films was related to the "volume random" and "surface columnar" crystallization phenomena, highlighting a linear relationship between the refractive index and the polysilicon volume fraction and, showing complex residual stress dependency with process conditions. Finally, by introducing the ratio $\mathrm{V}_{\mathrm{d}} / \mathrm{V}_{\mathrm{c}}$ between the deposition and crystallization rates as a major parameter, different deposition behaviours and related semi-empirical relationships were defined in order to characterize fully the various properties of LPCVD silicon films (microstructure, polysilicon volume fraction, refractive index and residual stress) according to the chosen gaseous source, silane or disilane.
\end{abstract}

Keywords: low-pressure chemical vapour deposition, thin films, silicon 


\section{Introduction}

In the context of microtechnologies, the properties of silicon films deposited by lowpressure chemical vapour deposition (LPCVD) were thoroughly studied. The investigations have mainly concerned the silane $\mathrm{SiH}_{4}$ gaseous source [1-17]. They evidenced that the deposition temperature $\mathrm{T}$, the $\mathrm{SiH}_{4}$ partial pressure $\mathrm{P}$ and/or the deposition rate $\mathrm{V}_{\mathrm{d}}$ were the main parameters for understanding the silicon films properties: cristallinity, microstructure, roughness, residual stress, $\ldots$

In parallel, the disilane $\mathrm{Si}_{2} \mathrm{H}_{6}$ gaseous source was also studied [18-21]. Compared to silane $\mathrm{SiH}_{4}$, its main advantage is related to the deposition of amorphous silicon films at low temperature $\left(420-520^{\circ} \mathrm{C}\right)$, i.e. lower than the silicon crystallization temperature $\left(\approx 580^{\circ} \mathrm{C}\right)$. Therefore, thanks to the disilane $\mathrm{Si}_{2} \mathrm{H}_{6}$ gaseous source, it was possible to separate the influence of the deposition and crystallization phenomena in order to understand better the silicon films properties (amorphous structure, crystallization kinetics, polycrystalline grains morphology, and residual stress) according to the deposition parameters: deposition temperature $\mathrm{T}, \mathrm{Si}_{2} \mathrm{H}_{6}$ partial pressure $\mathrm{P}$ and/or deposition rate $\mathrm{V}_{\mathrm{d}}$.

Nevertheless, in order to better understand silicon films properties, it is interesting to study in parallel the silane $\mathrm{SiH}_{4}$ and the disilane $\mathrm{Si}_{2} \mathrm{H}_{6}$ gaseous sources. This paper proposes such a study for silicon films deposited from both gaseous sources on a wide temperature range $\left(420-750^{\circ} \mathrm{C}\right)$. It presents a complete synthesis of results while introducing the ratio $\mathrm{V}_{\mathrm{d}} / \mathrm{V}_{\mathrm{c}}$ between the deposition and crystallization rates as a major influencing parameter.

\section{Experimental details}

Growth experiments were carried out in a conventional hot-wall, horizontal, LPCVD furnace. Using a full load of six test wafers and at least six screen wafers, thin silicon films (thickness range: $200-600 \mathrm{~nm}$ according to deposition conditions and times) were deposited 
on 4-inch, around 525- $\mu \mathrm{m}$ thick, (111), oxidised (around $120 \mathrm{~nm}$ thermal oxide) silicon substrates. Two gaseous sources, i.e. disilane $\mathrm{Si}_{2} \mathrm{H}_{6}$ and silane $\mathrm{SiH}_{4}$, were used in order to study the silicon deposition process on a large temperature range, i.e. from 420 to $750^{\circ} \mathrm{C}$. For the two gaseous sources, the deposition conditions, i.e. temperature $\mathrm{T}$, total pressure $\mathrm{P}$, gas flow $\mathrm{f}$ and wafer-to-wafer distance $\delta$, are detailed in table 1. Except for the deposition experiment from silane $\mathrm{SiH}_{4}$ at $750^{\circ} \mathrm{C}$ (see section 3.1), in each case and whatever the other deposition parameters, the gas flow $\mathrm{f}$ was chosen so that the deposition kinetics is controlled by the temperature rather than by mass transfer.

Silicon films thickness $e_{d}$ and refractive index n830nm were measured by ellipsometry at a 830nm wavelength. Deposition thickness $e_{d}$ was also checked by profilometry after the partial removal of the silicon upper film by chemical etching into the solution $\mathrm{HNO}_{3}\left(50 \mathrm{~cm}^{3}\right)$ $\mathrm{CH}_{3} \mathrm{COOH}\left(20 \mathrm{~cm}^{3}\right)-\mathrm{HF}\left(2 \mathrm{~cm}^{3}\right)$. Finally, deposition rates $\mathrm{V}_{\mathrm{d}}$ were calculated by dividing the deposition thickness $e_{d}$ by the deposition time $t_{d}$. The accuracy of these measurements was estimated to be $\pm 1 \%$.

The wafer curvature shift $\delta \rho$ before and after removal of the backside deposition by chemical etching (see below) was also determined by profilometry. Since the deposited silicon film is very thin compared to the silicon substrate $\left(e_{d}<<e_{s}\right)$, its average stress $\sigma$ was finally calculated thanks to the Stoney's formula [22]:

$$
\sigma=\frac{G_{s} e_{s}^{2}}{6 e_{d}} \delta \rho
$$

where $e_{d}$ is the deposited film thickness, and $e_{s}$ and $G_{s}$ are the silicon substrate thickness and elasticity coefficient respectively. The accuracy of the whole technique was estimated at $\pm 5 \%$.

Thermal annealing processes were performed at $600^{\circ} \mathrm{C}$ into a conventional furnace under nitrogen $\left(\mathrm{N}_{2}\right)$ ambient. Silicon microstructures were finally analyzed by scanning electron microscopy (SEM) observations after preparing the samples into a SECCO solution (HF: $13.33 \%$ and $\mathrm{K}_{2} \mathrm{Cr}_{2} \mathrm{O}_{7}: 0.05 \mathrm{~mol} / \mathrm{L}$ ) in order to reveal the polysilicon grains by etching the amorphous grain boundaries. Thanks to the SEM images, the surface ratio $r$ between the 
polycrystalline phases (clear areas) surface and the total scanned surface was thus calculated, and the polysilicon volume fraction $\mathrm{f}_{\mathrm{p}-\mathrm{Si}}$ was finally estimated according to the following equation:

$$
f_{p-\mathrm{Si}}=r^{3 / 2}
$$

All in all, the accuracy for the determination of the polysilicon volume fraction $f_{p-S i}$ was not worse than $\pm 8 \%$.

\section{Results and discussion}

\subsection{Deposition kinetics}

The deposition kinetics related to the silane $\mathrm{SiH}_{4}$ and disilane $\mathrm{Si}_{2} \mathrm{H}_{6}$ gaseous sources were studied according to the different deposition pressures (figure 1). Even if some consumption effects were evidenced for the deposition experiment from silane $\mathrm{SiH}_{4}$ at $750^{\circ} \mathrm{C}$, typical Arrhenius laws were found for both gaseous sources:

$$
V_{d}=V_{d_{0}} \exp \left(-\frac{E_{a}}{\mathrm{kT}}\right)
$$

where the $\mathrm{V}_{\mathrm{d} 0}$ parameters depend only on the deposition total pressure $\mathrm{P}$ and on the wafer-towafer distance $\delta$, and the activation energies $E_{a}$ were estimated to be $1.5 \mathrm{eV}$ and $2.25 \mathrm{eV}$ for the silane $\mathrm{SiH}_{4}$ and disilane $\mathrm{Si}_{2} \mathrm{H}_{6}$ gaseous sources, respectively.

In order to explain such results, the chemical reactions in gaseous phase were studied. From a general point of view and introducing the silylene radical $\mathrm{SiH}_{2}$, the pyrolysis reactions of silanes $\mathrm{Si}_{n} \mathrm{H}_{2 \mathrm{n}+2}$ can be written as follows [23]:

- $\quad \mathrm{Si}_{\mathrm{n}} \mathrm{H}_{2 \mathrm{n}+2}<------>\mathrm{Si}_{\mathrm{n}-1} \mathrm{H}_{2 \mathrm{n}}+\mathrm{SiH}_{2}$

- $\quad \mathrm{Si}_{\mathrm{n}} \mathrm{H}_{2 \mathrm{n}+2}<------>\mathrm{nSi} \mathrm{i}_{\text {adsorbed }}+(\mathrm{n}+1) \mathrm{H}_{2}$

- $\quad \mathrm{SiH}_{2}------>\mathrm{Si}_{\text {adsorbed }}+\mathrm{H}_{2}$

For the silane $\mathrm{SiH}_{4}$ gaseous source, this reactions system can be limited to the first order $(\mathrm{n}=1)$. Nevertheless, since the synthesis of silylene $\mathrm{SiH}_{2}$ from silane $\mathrm{SiH}_{4}$ is negligible (or 
weak) in the chosen deposition temperature range $\left(520-750^{\circ} \mathrm{C}\right)$ [23], the silicon deposition is mainly due to the silane $\mathrm{SiH}_{4}$ pyrolysis:

- $\quad \mathrm{SiH}_{4}$------> $\mathrm{Si}_{\text {adsorbed }}+2 \mathrm{H}_{2}$

For the disilane $\mathrm{Si}_{2} \mathrm{H}_{6}$ gaseous source, the reactions in gaseous phase involve both first and second orders $(\mathrm{n}=1$ and $\mathrm{n}=2)$. However, since the silane $\mathrm{SiH}_{4}$ pyrolysis is very low for the chosen deposition temperature $\left(420-520^{\circ} \mathrm{C}\right)$, the silicon deposition is mainly due to the synthesis of silylene $\mathrm{SiH}_{2}$ from disilane $\mathrm{Si}_{2} \mathrm{H}_{6}$ and finally to the silylene $\mathrm{SiH}_{2}$ pyrolysis:

- $\mathrm{Si}_{2} \mathrm{H}_{6}<------>\mathrm{SiH}_{4}+\mathrm{SiH}_{2}$

- $\quad \mathrm{SiH}_{2}------>\mathrm{Si}_{\text {adsorbed }}+\mathrm{H}_{2}$

Thus, compared to silane $\mathrm{SiH}_{4}$, the interest in using disilane $\mathrm{Si}_{2} \mathrm{H}_{6}$ is related to the introduction of a large amount of silylene $\mathrm{SiH}_{2}$ species into the gaseous phase. Since this radical is very reactive, it is responsible for a higher activation energy $E_{a}$ and finally for higher deposition rates for a given deposition temperature (figure 1).

In previous works, the ratio between the deposition rate $\mathrm{V}_{\mathrm{d}}$ and the crystallization rate $\mathrm{V}_{\mathrm{c}}$ was introduced as a major parameter in order to define the silicon films properties $[5,24]$. Furthermore, Guillemet et al. have shown that silicon crystallization kinetic is characterized by a typical Arrhenius law:

$$
V_{c}=V_{c_{0}} \exp \left(-\frac{E_{c}}{\mathrm{kT}}\right)
$$

where the activation energy $\mathrm{E}_{\mathrm{c}}$ and the parameter $\mathrm{V}_{\mathrm{c} 0}$ were respectively estimated to be $2.5 \mathrm{eV}$ and $1.610^{15} \mathrm{~nm} / \mathrm{min}[25]$.

Finally, $V_{d} / V_{c}$ ratios were calculated according to equations (3) and (4). Thus, while investigating commonly both silane $\mathrm{SiH}_{4}$ and disilane $\mathrm{Si}_{2} \mathrm{H}_{6}$ gaseous sources, the properties of LPCVD silicon film were studied for $\mathrm{V}_{\mathrm{d}} / \mathrm{V}_{\mathrm{c}}$ values ranging from $10^{-2}$ to $10^{3}$.

\subsection{Refractive index}


The refractive index at the $830 \mathrm{~nm}$ wavelength $\mathrm{n} 830 \mathrm{~nm}$ was investigated versus the $\mathrm{V}_{\mathrm{d}} / \mathrm{V}_{\mathrm{c}}$ ratio for both silane $\mathrm{SiH}_{4}$ and disilane $\mathrm{Si}_{2} \mathrm{H}_{6}$ gaseous sources (figure 2). For the as-deposited silicon films, a refractive index transition from 4.0 to 3.7 is evidenced for a $V_{d} / V_{c}$ value around 1. Since this transition no longer exists after a 15 -hours crystallization anneal at $600^{\circ} \mathrm{C}$, it should be related to the transition from amorphous silicon $\left(\mathrm{n}_{\mathrm{a}-\mathrm{Si}}=4.00\right)$ and polycrystalline silicon $\left(\mathrm{n}_{\mathrm{p}-\mathrm{Si}}=3.70\right)[14,17,26]$. This was confirmed by studying the refractive index variations with the $600^{\circ} \mathrm{C}$ annealing duration for two amorphous silicon films deposited from silane $\mathrm{SiH}_{4}$ $\left(\mathrm{T}=555^{\circ} \mathrm{C} ; \mathrm{P}=26.66 \mathrm{~Pa} ; \mathrm{V}_{\mathrm{d}} / \mathrm{V}_{\mathrm{c}} \approx 2.3\right)$ and disilane $\mathrm{Si}_{2} \mathrm{H}_{6}\left(\mathrm{~T}=465^{\circ} \mathrm{C} ; \mathrm{P}=26.66 \mathrm{~Pa} ; \mathrm{V}_{\mathrm{d}} / \mathrm{V}_{\mathrm{c}} \approx\right.$ 250) gaseous sources, respectively (figure 3).

In order to explain this transition, silicon has to be considered as a heterogeneous medium between a polycrystalline phase and an amorphous one. Thus, since the silicon crystallites size $(\approx 1 \mu \mathrm{m})$ is of the same order of magnitude as the wavelength (figure 4$)$ and considering that the optical index is a macroscopic parameter that does not depend on the intrinsic microstructure, the Bruggeman theory gives [27]:

$$
\begin{aligned}
& f_{p-\mathrm{Si}} \frac{n_{p-\mathrm{Si}}^{2}-n^{2}}{n_{p-\mathrm{Si}}^{2}+2 n^{2}}+f_{a-\mathrm{Si}} \frac{n_{a-\mathrm{Si}}^{2}-n^{2}}{n_{a-\mathrm{Si}}^{2}+2 n^{2}}=0 \\
& f_{p-\mathrm{Si}}+f_{a-\mathrm{Si}}=1
\end{aligned}
$$

where $\mathrm{f}_{\mathrm{p}-\mathrm{Si}}, \tilde{\mathrm{n}}_{\mathrm{p}-\mathrm{Si}}, \mathrm{f}_{\mathrm{a}-\mathrm{Si}}$ and $\tilde{\mathrm{n}}_{\mathrm{a}-\mathrm{Si}}$, are the volume fractions and optical indexes of the polycrystalline silicon and amorphous silicon phases respectively.

At the $830 \mathrm{~nm}$ wavelength and whether the microstructure is amorphous or polycrystalline, the extinction coefficient $\mathrm{k}_{830 \mathrm{~nm}}$ of silicon is very low $\left(\mathrm{k}_{830 \mathrm{~nm}} \approx 0.005\right)$ compared to its refractive index $\mathrm{n}_{830 \mathrm{~nm}}\left(3.7 \leq \mathrm{n}_{830 \mathrm{~nm}} \leq 4\right)$. Thus, the optical index imaginary part can be neglected in the Bruggeman equation:

$$
\Re_{830 \mathrm{~nm}}=n_{830 \mathrm{~nm}}-\mathrm{ik}_{830 \mathrm{~nm}} \gg n_{830 \mathrm{~nm}}
$$

Therefore, knowing that $\mathrm{n}_{\mathrm{p}-\mathrm{Si}}=3.70$ and $\mathrm{n}_{\mathrm{a}-\mathrm{Si}}=4.00$ (see before) and according to equations 5 to 7 , it is now possible to determine the polysilicon volume fraction $\mathrm{f}_{\mathrm{p}-\mathrm{Si}}$ as a function of the silicon film refractive index n830nm: 


$$
f_{p-\mathrm{Si}}=-\frac{2\left(n_{830 \mathrm{~nm}}\right)^{4}-18.31\left(n_{830 \mathrm{~nm}}\right)^{2}-219.04}{6.93\left(n_{830 \mathrm{~nm}}\right)^{2}}
$$

From equation 8 , obtaining a numeric relation giving the silicon film refractive index $\mathrm{n}_{830 \mathrm{~nm}}$ as a function of the polysilicon volume fraction $\mathrm{f}_{\mathrm{p}-\mathrm{Si}}$ is possible but very intricate. In fact, it is more practical to use a simple linear interpolation of the theoretical curve (with an error lower than $1 \%)$ :

$$
n_{830 \mathrm{~nm}} \approx 4-0.3 f_{p-\mathrm{Si}}
$$

In order to go further, the amorphous/polycrystalline transition was studied by scanning electron microscopy (SEM) for the two previously defined amorphous samples (figure 4). Typically, the SEM pictures evidenced the growth of polysilicon grains, starting from an amorphous silicon (a-Si) microstructure and leading to a volume randomly polycrystalline silicon (rp-Si) one $[8,16,21,24,28]$. Nevertheless, by estimating the volume fraction of the polysilicon phase $f_{p-S i}$, a good fit was obtained with equation 9 (figure 5), demonstrating the impact of the crystallization phenomena on the silicon films refractive index.

\subsection{Residual stress}

The residual stress $\sigma$ was studied versus the $\mathrm{V}_{\mathrm{d}} / \mathrm{V}_{\mathrm{c}}$ ratio for both silane $\mathrm{SiH}_{4}$ and/or disilane $\mathrm{Si}_{2} \mathrm{H}_{6}$ gaseous sources (figures 6 and 7). Such complex variations will be explained by considering, (i) the amorphous silicon films obtained for $\mathrm{V}_{\mathrm{d}} / \mathrm{V}_{\mathrm{c}}>2$ with both gaseous sources, and (ii) the $\mathrm{SiH}_{4}$-deposited silicon films obtained for $\mathrm{V}_{\mathrm{d}} / \mathrm{V}_{\mathrm{c}}<5$.

\subsubsection{Residual stress into amorphous silicon films $\left(V_{d} / V_{c}>2\right)$}

First, for the disilane $\mathrm{Si}_{2} \mathrm{H}_{6}$ gaseous source, i.e. for the highest $\mathrm{V}_{\mathrm{d}} / \mathrm{V}_{\mathrm{c}}$ ratios $\left(\mathrm{V}_{\mathrm{d}} / \mathrm{V}_{\mathrm{c}}>\right.$ 50), the silylene $\mathrm{SiH}_{2}$ pyrolysis is responsible for high hydrogen contents into the deposited amorphous silicon films [14-16]. Thus, as-deposited, dehydrogenated (thanks to a 15-minutes 
anneal at $600^{\circ} \mathrm{C}$ ), and annealed (thanks to a 15 -hours crystallization anneal at $600^{\circ} \mathrm{C}$ ) samples were studied (figure 7). As a first result, it appears that the residual stress into dehydrogenated silicon film follows globally linear variations with the $\mathrm{V}_{\mathrm{d}} / \mathrm{V}_{\mathrm{c}}$ ratio:

$$
\mathrm{Si}_{2} H_{6}: \sigma_{\text {dehydrogenated }}(\mathrm{MPa}) \approx-300+0.7 \frac{V_{d}}{V_{c}}
$$

In previous works, the properties of amorphous silicon films deposited from disilane $\mathrm{Si}_{2} \mathrm{H}_{6}$ were related to deposition and germination phenomena by introducing their structural disorder and hydrogen content as main parameters [19]. Thus, since germination and crystallization kinetics are following similar Arrhenius laws [25], the residual stress $\sigma$ can be written as follows [21]:

$$
\mathrm{Si}_{2} H_{6}: \sigma \approx S \sigma_{[H]}+\sigma_{\left(V_{d} / V_{c}\right)}
$$

Consequently, according to equations (10) and (11), the residual stress $\sigma$ of amorphous deposited films deposited from disilane $\mathrm{Si}_{2} \mathrm{H}_{6}$ is given by:

$$
\mathrm{Si}_{2} H_{6}: \sigma_{a-\mathrm{Si}}(\mathrm{MPa}) \approx \sigma_{[H]}-300+0.7 \frac{V_{d}}{V_{c}}
$$

From figure 7, it appears that the residual stress $\sigma$ into as-deposited silicon films and therefore the $\sigma_{[\mathrm{H}]}$ parameter follow complex non-linear variations, especially for the lowest $\mathrm{V}_{\mathrm{d}} / \mathrm{V}_{\mathrm{c}}$ ratios. This prevents the full understanding of the properties of amorphous silicon films deposited from disilane $\mathrm{Si}_{2} \mathrm{H}_{6}$.

Second, it appears in figure 7 that, whatever the deposition conditions, the residual stress of randomly polycrystalline silicon (rp-Si) films, deposited from disilane $\mathrm{Si}_{2} \mathrm{H}_{6}$ and annealed at $600^{\circ} \mathrm{C}$, is tensile, equal to about $+425 \mathrm{MPa}$.

$$
\mathrm{Si}_{2} H_{6}: \sigma_{\mathrm{rp}-\mathrm{Si}} \approx+425 \mathrm{MPa}
$$

Then, since silicon films deposited from silane $\mathrm{SiH}_{4}$ in the [2-5] $\mathrm{V}_{\mathrm{d}} / \mathrm{V}_{\mathrm{c}}$ range are still amorphous, an analysis similar to the previous one was undertaken (figure 6). In this case, since the silane $\mathrm{SiH}_{4}$ pyrolysis and the use of higher deposition temperatures are not responsible for hydrogenation effect, dehydrogenated samples were no longer studied. It appears that, whatever 
the deposition conditions, the residual stresses into as-deposited and annealed (thanks to a 15hours crystallization anneal at $600^{\circ} \mathrm{C}$ ) silicon films deposited from silane $\mathrm{SiH}_{4}$ are respectively compressive $(\approx-300 \mathrm{MPa})$ and tensile $(\approx+250 \mathrm{MPa})$. These results should be related to the amorphous (a-Si) and randomly polycrystalline (rp-Si) silicon microstructure (see below):

$$
\begin{aligned}
& \mathrm{SiH}_{4}: \sigma_{a-\mathrm{Si}} \approx-300 \mathrm{MPa} \\
& \mathrm{SiH}_{4}: \sigma_{\mathrm{rp}-\mathrm{Si}} \approx+250 \mathrm{MPa}
\end{aligned}
$$

To further investigate this point, the residual stress variations with the $600^{\circ} \mathrm{C}$ annealing duration were studied for the two previously defined (see section 3.2) amorphous samples (figure 8). After the initial increase due to the dehydrogenation for the sample deposited from disilane $\mathrm{Si}_{2} \mathrm{H}_{6}$, it appears clearly that the volume random crystallization is responsible for the residual stress increase from compressive to tensile stress [21,29]. Since sigmoid variations were evidenced in figures 4 and 8 , the residual stress $\sigma$ of silicon films annealed at $600^{\circ} \mathrm{C}$ was studied versus the polysilicon volume fraction $\mathrm{f}_{\mathrm{p}-\mathrm{Si}}$ (figure 9). A linear relation was thus evidenced for both samples:

$$
\sigma=\sigma_{a-S \mathrm{i}}+f_{p-\mathrm{Si}}\left(\sigma_{\mathrm{rp}-\mathrm{Si}}-\sigma_{a-\mathrm{Si}}\right)
$$

In the case of the silane $\mathrm{SiH}_{4}$ gaseous source, the $\sigma_{\mathrm{a}-\mathrm{Si}}$ and $\sigma_{\mathrm{rp}-\mathrm{Si}}$ values are constant whatever the deposition conditions and the residual stress $\sigma$ of silicon films depends finally only on the polysilicon volume fraction $\mathrm{f}_{\mathrm{p}-\mathrm{Si}}$ :

$$
\mathrm{SiH}_{4}: \sigma(\mathrm{MPa}) \approx-300+550 f_{p-\mathrm{Si}}
$$

Finally, in the [5-50] $\mathrm{V}_{\mathrm{d}} / \mathrm{V}_{\mathrm{c}}$ ratio range, it appears that continuity could exist between the non-hydrogenated amorphous silicon films deposited from silane $\mathrm{SiH}_{4}$ and dehydrogenated amorphous silicon films deposited from disilane $\mathrm{Si}_{2} \mathrm{H}_{6}$ (figure 6). Assuming this continuity and according to equations (12), (13) and (16), the residual stress of silicon films deposited from disilane $\mathrm{Si}_{2} \mathrm{H}_{6}$ is finally given by:

$$
\mathrm{Si}_{2} H_{6}: \sigma(\mathrm{MPa}) \approx\left(\sigma_{[H]}-300+0.7 \frac{V_{d}}{V_{c}}\right)\left(1-f_{p-S \mathrm{i}}\right)+425 f_{p-\mathrm{Si}}
$$


Concerning the final stress value $\sigma_{\mathrm{rp}-\mathrm{Si}}$, the discontinuity between silane $\mathrm{SiH}_{4}$ and disilane $\mathrm{Si}_{2} \mathrm{H}_{6}$ is obvious. Since the $\sigma_{\mathrm{rp}-\mathrm{Si}}$ values obtained for each gaseous source are constant whatever the deposition conditions, their difference should be related to LPCVD fundamentals, and therefore to the main chemical species responsible for the silicon films deposition in gaseous phase (see section 3.1).

\subsubsection{Residual stress into silicon films deposited from silane $\mathrm{SiH}_{4}\left(V_{d} / V_{c}<5\right)$}

For the silane $\mathrm{SiH}_{4}$ gaseous source $\left(\mathrm{V}_{\mathrm{d}} / \mathrm{V}_{\mathrm{c}}<5\right)$, as-deposited and annealed $\left(600^{\circ} \mathrm{C}-15\right.$ hours) silicon films are characterized by typical compressive/tensile/compressive and tensile/compressive stress transitions respectively (figure 6). Such results were related to the competition between deposition and crystallization phenomena [24].

Starting from amorphous silicon (a-Si) films obtained in the [2-5] $\mathrm{V}_{\mathrm{d}} / \mathrm{V}_{\mathrm{c}}$ range (see below), the $V_{d} / V_{c}$ decrease leads to the deposition of randomly semi-crystallized silicon (s-Si) due to the polysilicon grains growth during the silicon deposition process. As already shown in figure 8 , this volume random crystallization is responsible for tensile stress and therefore for a residual stress increase. Further annealing leads to the films' complete crystallization and the residual stress of annealed films reached: $\sigma_{\mathrm{rp}-\mathrm{Si}}=+250 \mathrm{MPa}$ (see below).

For a further $\mathrm{V}_{\mathrm{d}} / \mathrm{V}_{\mathrm{c}}$ decrease, the direct deposition of polycrystalline silicon also called surface crystallization (see hereafter) takes gradually over the volume random crystallization. Thus, the silicon microstructure becomes a mixture between randomly and columnar crystallized phases [17]. These mixed polycrystalline silicon (mp-Si) films are obtained while residual stress decreases rapidly towards compressive values (around -500 MPa). Since these films are almost completely crystallized as deposited, further anneal gives little stress variations.

Then, when the $\mathrm{V}_{\mathrm{d}} / \mathrm{V}_{\mathrm{c}}$ ratio keeps on decreasing, crystallization of Si-Si bonds occurs as soon as silicon atoms are adsorbed at the silicon surface. This surface crystallization is known to lead to a columnar polysilicon (cp-Si) microstructure and compressive stress 
$[16,24,28,30]$. The silicon films residual stress is finally shown to be compressive, starting from $-500 \mathrm{MPa}$ and increasing towards $0 \mathrm{MPa}$ with the $\mathrm{V}_{\mathrm{d}} / \mathrm{V}_{\mathrm{c}}$ ratio decrease.

\subsection{Results synthesis}

All in all, by considering that the silicon films deposition and crystallization kinetics are estimated according to equations (3) and (4), five main deposition behaviours can been defined according to the gaseous source and the $\mathrm{V}_{\mathrm{d}} / \mathrm{V}_{\mathrm{c}}$ ratio range (table 2). These five behaviours, four for the silane $\mathrm{SiH}_{4}$ gaseous source and one for the disilane $\mathrm{Si}_{2} \mathrm{H}_{6}$, can be easily represented on the related Arrhenius diagram (figure 10). These relations allow to fully characterize the properties of LPCVD silicon films (microstructure, polysilicon volume fraction, refractive index and residual stress) whatever the gaseous source (silane $\mathrm{SiH}_{4}$ or disilane $\mathrm{Si}_{2} \mathrm{H}_{6}$ ) and the deposition/anneal conditions.

\section{Conclusion}

Silicon films obtained by low-pressure chemical vapour deposition from silane $\mathrm{SiH}_{4}$ and disilane $\mathrm{Si}_{2} \mathrm{H}_{6}$ were studied while choosing as main influent parameters the ratio $\mathrm{V}_{\mathrm{d}} / \mathrm{V}_{\mathrm{c}}$ between the deposition and crystallization rates as well as the polysilicon volume fraction $\mathrm{f}_{\mathrm{p}-\mathrm{Si}}$. Different silicon microstructures were deposited, i.e. amorphous (a-Si), randomly semicrystallized (s-Si), randomly polycrystallized (rp-Si), mixed-polycristallized (mp-Si) and columnar polycristallized (cp-Si), and the $\mathrm{V}_{\mathrm{d}} / \mathrm{V}_{\mathrm{c}}$ ratio's major influence was highlighted, evidencing five deposition behaviours and related semi-empirical relationships. It is thus possible to anticipate the properties of LPCVD silicon films (microstructure, polysilicon volume fraction, refractive index and residual stress) according to the gaseous source (silane $\mathrm{SiH}_{4}$ or disilane $\mathrm{Si}_{2} \mathrm{H}_{6}$ ) and to the deposition/anneal conditions.

To have a complete understanding of the silicon films properties, the hydrogenation influence on the residual stress (see section $3.3-\sigma_{[\mathrm{H}]}$ parameter) and the final stress of random 
polysilicon (see section $3.3-\sigma_{\mathrm{rp}-S i}$ parameter) have to be studied. This could be reached by investigating the $[5-50] \mathrm{V}_{\mathrm{d}} / \mathrm{V}_{\mathrm{c}}$ ratio range. For technological reasons, it is no longer possible to decrease the deposition temperature under $520^{\circ} \mathrm{C}$ for the silane $\mathrm{SiH}_{4}$ gaseous source. Similarly, it is no longer possible to increase the deposition temperature above $520^{\circ} \mathrm{C}$ for the disilane $\mathrm{Si}_{2} \mathrm{H}_{6}$ gaseous source. It is still possible to reduce the disilane pressure at $520^{\circ} \mathrm{C}$ to values lower than $13.33 \mathrm{~Pa}$ but little $\mathrm{V}_{\mathrm{d}} / \mathrm{V}_{\mathrm{c}}$ decrease under 50 will be reached in this way. In fact, the solution requires performing silicon films deposition experiments at $520^{\circ} \mathrm{C}$ while using a $\mathrm{SiH}_{4} / \mathrm{Si}_{2} \mathrm{H}_{6}$ gaseous mixture in a specifically adapted LPCVD furnace.

\section{References}

[1] T.I. Kamins, J. Electrochem. Soc. 127-230 (1980) 686.

[2] G. Harbercke, L. Krausbauer, E.F. Steigmeier, A.E. Widmer, H.F. Kappert, G. Neugebauer, J. Electrochem. Soc. 131 (1984) 675.

[3] R. Bisaro, J. Magarino, N. Proust, K. Zellama, J. Appl. Phys. 59 (1986) 1167.

[4] P. Joubert, B. Loisel, Y. Chouan, L. Haji, J. Electrochem. Soc. 134 (1987) 2541.

[5] P. Krulevitch, T.D. Nguyen, G.C. Johnson, R.T. Howe, H.R. Wenk, R. Gronsky, Materials Research Society Symposium Proceedings 202 (1991) 67.

[6] A.T. Voutsas, M.K. Hatalis, J. Electrochem. Soc. 139 (1992) 2659.

[7] E.G. Lee, S.K. Rha, J. Mat. Sci. 28 (1993) 6279.

[8] A.T. Voutsas, M.K. Hatalis, J. Electrochem. Soc. 140 (1993) 282.

[9] A.T. Voutsas, M.K. Hatalis, J. Electron. Mater. 23 (1994) 319.

[10] L. Wei, M. Vaudin, C.S. Hwang, G. White, J. Xu, A.J. Steckl, J. Mater. Res. 10 (1995) 1889.

[11] A.T. Voutsas, M.K. Hatalis, J. Boyce, A. Chiang, J. Appl. Phys. 78 (1995) 6999.

[12] J.H. Kim, J.Y. Lee, K.S. Nam, J. Appl. Phys. 79 (1996) 1794. 
[13] T. Mohammed-Brahim, K. Kis-Sion, D. Briand, M. Sarret, O. Bonnaud, J.P. Kleider, C. Longeaud, J. Non-Cryst. Solids 227-230 (1998) 962.

[14] M. Gartner, M. Modreanu, C. Cobianu, R. Gavrila, M. Danila, Sens. Actuators, A 99 (2002) 160 .

[15] R. Edrei, E.N. Shauly, Y. Roizin, A. Hoffman, Appl. Surf. Sci. 188 (2002) 539.

[16] H.W. Zhou, B.G. Kharas, P.I. Gouma, Sens. Actuators, A 104 (2003) 1.

[17] M. Modreanu, M. Gartner, C. Cobianu, B. O'Looney, F. Murphy, Thin Solid films, 450 (2004) 105.

[18] E. Scheid, B. de Mauduit, P. Taurines, D. Bielle Daspet, Jpn. J. Appl. Phys. 27 (1990) 2105.

[19] N. Nakazawa, Jpn. J. Appl. Phys. 69 (1991) 1703.

[20] E. Scheid, J.J. Pedroviejo, P. Duverneuil, M. Gueye, J. Samitier, A. El Hassani, D. Bielle Daspet, Mater. Sci. Eng. B17 (1993) 72.

[21] P. Temple-Boyer, E. Scheid, G. Faugere, B. Rousset, Thin Solid Films 310 (1997) 234.

[22] G.G. Stoney, Proc. Roy. Soc. London 9 (1909) 172.

[23] C. Azzaro, P. Duverneuil, J.P. Couderc, Int. Chem. Eng. 34 (1994) 59.

[24] P. Temple-Boyer, B. de Mauduit, B. Caussat, J.P. Couderc, J. Phys. IV 9 (1999) 1107.

[25] J.P. Guillemet, B. de Mauduit, B. Pierraggi, D. Bielle Daspet, E. Scheid, Mater. Sci. Eng., A 173 (1993) 377.

[26] E. Ibok, S. Garg, J. Electrochem. Soc. 140 (1993) 2927.

[27] D.E. Aspnes, Thin Solid Films 65 (1982) 249.

[28] E. Kinsbron, M. Sternheim, R. Knoell, Appl. Phys. Lett. 42 (1983) 835.

[29] J. Yang, H. Kahn, A.G. He, S.M. Phillips, A.H. Heuer, IEEE J. Micromech. Syst. 9 (2000) 485.

[30] H. Cerva, J. Mater. Res. 6 (1991) 2324. 


\section{Tables and figures captions}

Table 1: LPCVD deposition parameters ranges

for the silane $\mathrm{SiH}_{4}$ and disilane $\mathrm{Si}_{2} \mathrm{H}_{6}$ gaseous sources

Table 2: main LPCVD deposition behaviours and related semi-empirical relationships according to the gaseous source and the $\mathrm{V}_{\mathrm{d}} / \mathrm{V}_{\mathrm{c}}$ ratio range

Figure 1: Deposition kinetics for the silane $\mathrm{SiH}_{4}$ and disilane $\mathrm{Si}_{2} \mathrm{H}_{6}$ gaseous sources

Figure 2: Refractive index as $n_{830 n m}$ versus $V_{d} / V_{c}$ ratio for as-deposited and annealed silicon films

Figure 3: Refractive index variation with annealing duration for amorphous silicon films deposited from silane $\mathrm{SiH}_{4}$ and disilane $\mathrm{Si}_{2} \mathrm{H}_{6}$ gaseous sources

Figure 4: Microstructures of silicon films for different annealing durations at $600^{\circ} \mathrm{C}$ for the silane $\mathrm{SiH}_{4}$ and disilane $\mathrm{Si}_{2} \mathrm{H}_{6}$ gaseous sources

Figure 5: Refractive index $\mathrm{n}_{830 \mathrm{~nm}}$ versus polysilicon volume fraction $\mathrm{f}_{\mathrm{p}-\mathrm{Si}}$

Figure 6: Residual stress $\sigma$ versus $\mathrm{V}_{\mathrm{d}} / \mathrm{V}_{\mathrm{c}}$ ratio

for as-deposited, dehydrogenated and annealed silicon films 
Figure 7: Residual stress $\sigma$ versus $\mathrm{V}_{\mathrm{d}} / \mathrm{V}_{\mathrm{c}}$ ratio

for as-deposited, dehydrogenated and annealed silicon films

(zoom on the disilane $\mathrm{Si}_{2} \mathrm{H}_{6}$ gaseous source)

Figure 8: Residual stress index variation with annealing duration for amorphous silicon films deposited from silane $\mathrm{SiH}_{4}$ and disilane $\mathrm{Si}_{2} \mathrm{H}_{6}$ gaseous sources

Figure 9: Residual stress $\sigma$ versus polysilicon volume fraction $\mathrm{f}_{\mathrm{p}-\mathrm{Si}}$

Figure 10: Silicon microstructure versus deposition and crystallization kinetics 


\begin{tabular}{|c|c|c|}
\hline gaseous source & silane $\mathrm{SiH}_{4}$ & disilane $\mathrm{Si}_{2} \mathrm{H}_{6}$ \\
\hline temperature $\mathrm{T}$ & $520-750^{\circ} \mathrm{C}$ & $420-520^{\circ} \mathrm{C}$ \\
\hline total pressure $\mathrm{P}$ & $13.33-40 \mathrm{~Pa}$ & $13.33-53.33 \mathrm{~Pa}$ \\
\hline gas flow f & $50-150 \mathrm{sccm}$ & $40-160 \mathrm{sccm}$ \\
\hline wafer-to-wafer distance $\delta$ & $10 \mathrm{~mm}$ & $20 \mathrm{~mm}$ \\
\hline
\end{tabular}

Table 1: LPCVD deposition parameters ranges

for the silane $\mathrm{SiH}_{4}$ and disilane $\mathrm{Si}_{2} \mathrm{H}_{6}$ gaseous sources 


\begin{tabular}{|c|c|c|}
\hline $\begin{array}{l}\text { gaseous source } \\
\text { and } \mathrm{V}_{\mathrm{d}} / \mathrm{V}_{\mathrm{c}} \text { range }\end{array}$ & $\begin{array}{l}\text { silicon } \\
\text { microstructure }\end{array}$ & silicon film properties \\
\hline $\mathrm{SiH}_{4}: \mathrm{V}_{\mathrm{d}} / \mathrm{V}_{\mathrm{c}} \leq 1$ & $\begin{array}{l}\text { columnar } \\
\text { polysilicon }\end{array}$ & $\begin{array}{c}\mathrm{f}_{\mathrm{p}-\mathrm{Si}} \approx 1 \\
\mathrm{n}_{830 \mathrm{~nm}} \approx 3.7 \\
\sigma(\mathrm{MPa}) \approx-500 \exp \left[-2.6\left(1-\frac{V_{d}}{V_{c}}\right)^{2}\right]\end{array}$ \\
\hline $\mathrm{SiH}_{4}: 1 \leq \mathrm{V}_{\mathrm{d}} / \mathrm{V}_{\mathrm{c}} \leq 1.3$ & $\begin{array}{c}\text { mixed } \\
\text { polysilicon }\end{array}$ & $\begin{array}{c}\mathrm{f}_{\mathrm{p}-\mathrm{Si}} \approx 1 \\
\mathrm{n}_{830 \mathrm{~nm}} \approx 3.7 \\
\sigma(\mathrm{MPa}) \approx-500+4350 \ln \frac{V_{d}}{V_{c}}-7500\left(\ln \frac{V_{d}}{V_{c}}\right)^{2}\end{array}$ \\
\hline $\mathrm{SiH}_{4}: 1.3 \leq \mathrm{V}_{\mathrm{d}} / \mathrm{V}_{\mathrm{c}} \leq 1.7$ & $\begin{array}{l}\text { semi-crystallized } \\
\text { silicon }\end{array}$ & $\begin{array}{c}f_{p-\mathrm{Si}} \approx \frac{\sigma(\mathrm{MPa})+300}{550} \\
\mathrm{n} 830 \mathrm{~nm} \approx 4-0.3 \mathrm{f} \mathrm{p}-\mathrm{Si} \\
\sigma(\mathrm{MPa}) \approx-500+4350 \ln \frac{V_{d}}{V_{c}}-7500\left(\ln \frac{V_{d}}{V_{c}}\right)^{2}\end{array}$ \\
\hline $\mathrm{SiH}_{4}: 1.7 \leq \mathrm{V}_{\mathrm{d}} / \mathrm{V}_{\mathrm{c}} \leq 5$ & $\begin{array}{l}\text { amorphous } \\
\text { silicon }\end{array}$ & $\begin{array}{c}\mathrm{f}_{\mathrm{p}-\mathrm{Si}} \approx 0 \\
\mathrm{n}_{830 \mathrm{~nm}} \approx 4.0 \\
\sigma \approx-300 \mathrm{MPa}\end{array}$ \\
\hline $\mathrm{Si}_{2} \mathrm{H}_{6}: 50 \leq \mathrm{V}_{\mathrm{d}} / \mathrm{V}_{\mathrm{c}}$ & $\begin{array}{l}\text { amorphous } \\
\text { silicon }\end{array}$ & $\begin{array}{c}\mathrm{f}_{\mathrm{p}-\mathrm{Si}} \approx 0 \\
\mathrm{n}_{830 \mathrm{~nm}} \approx 4.0 \\
\sigma(\mathrm{MPa}) \approx \sigma_{[H]}-300+0.7 \frac{V_{d}}{V_{c}}\end{array}$ \\
\hline
\end{tabular}

Table 2: main LPCVD deposition behaviours and related semi-empirical relationships according to the gaseous source and the $\mathrm{V}_{\mathrm{d}} / \mathrm{V}_{\mathrm{c}}$ ratio range 


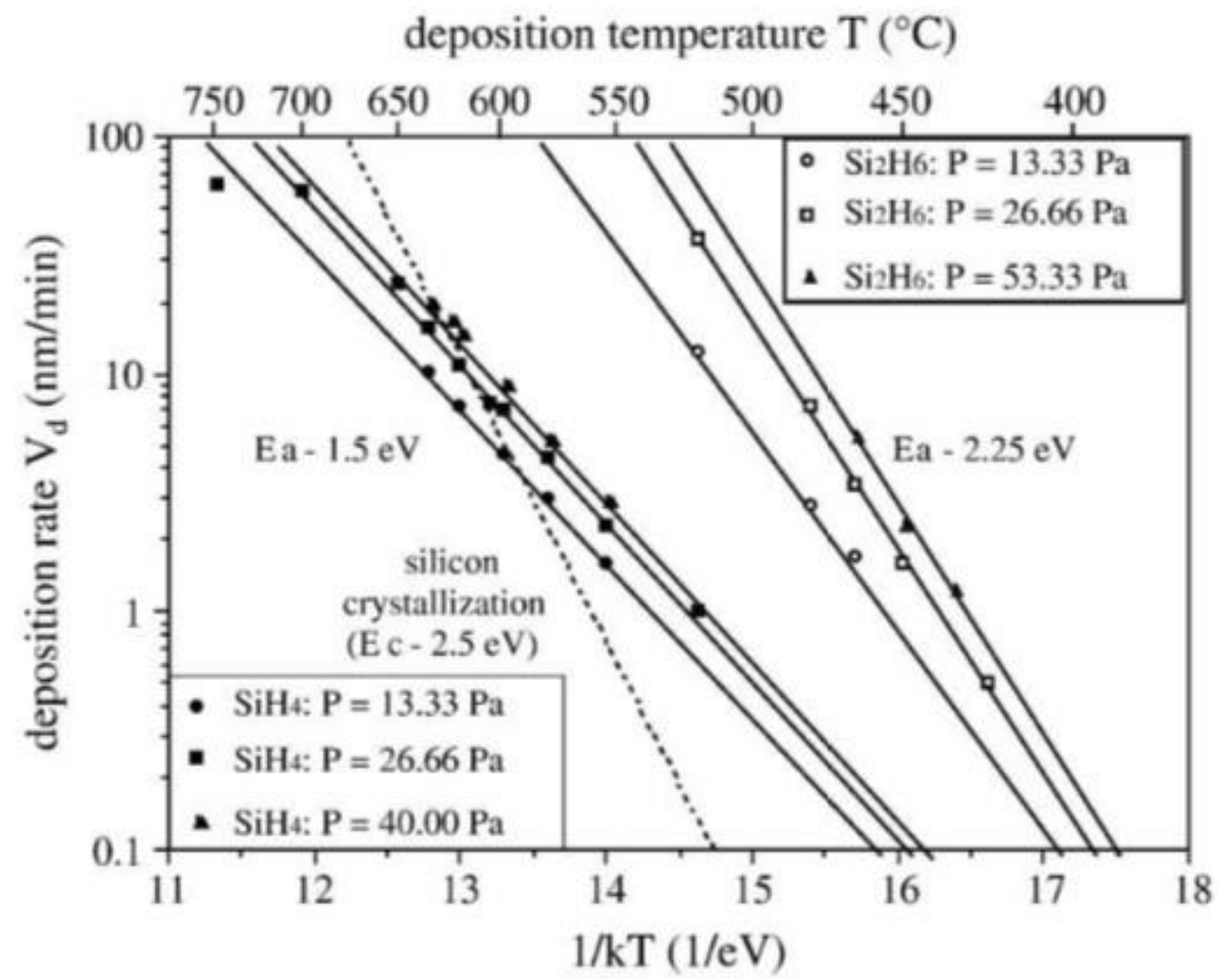

Figure 1: Deposition kinetics for the silane $\mathrm{SiH}_{4}$ and disilane $\mathrm{Si}_{2} \mathrm{H}_{6}$ gaseous sources 


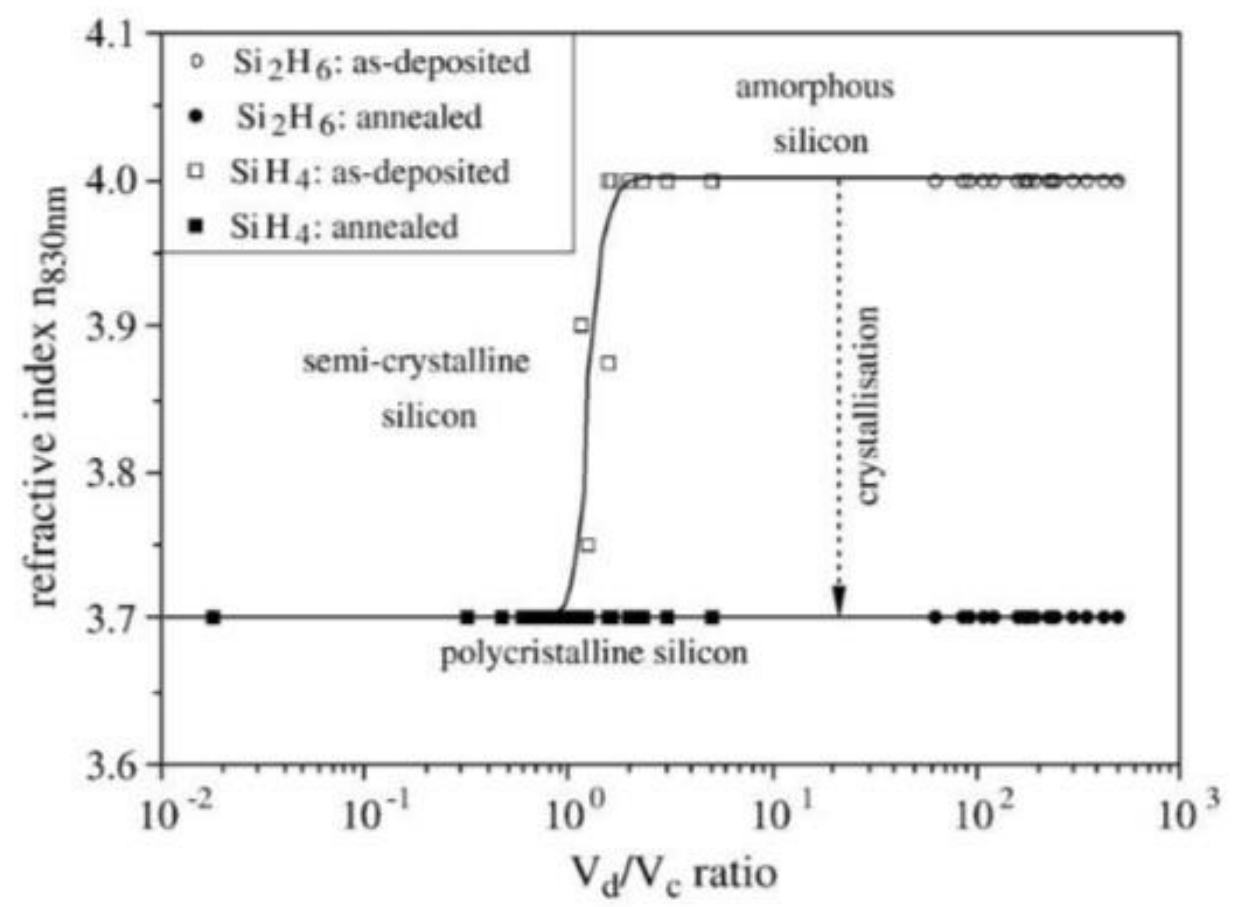

Figure 2: Refractive index $\mathrm{n}_{830 \mathrm{~nm}}$ versus $\mathrm{V}_{\mathrm{d}} / \mathrm{V}_{\mathrm{c}}$ ratio

for as-deposited and annealed silicon films 


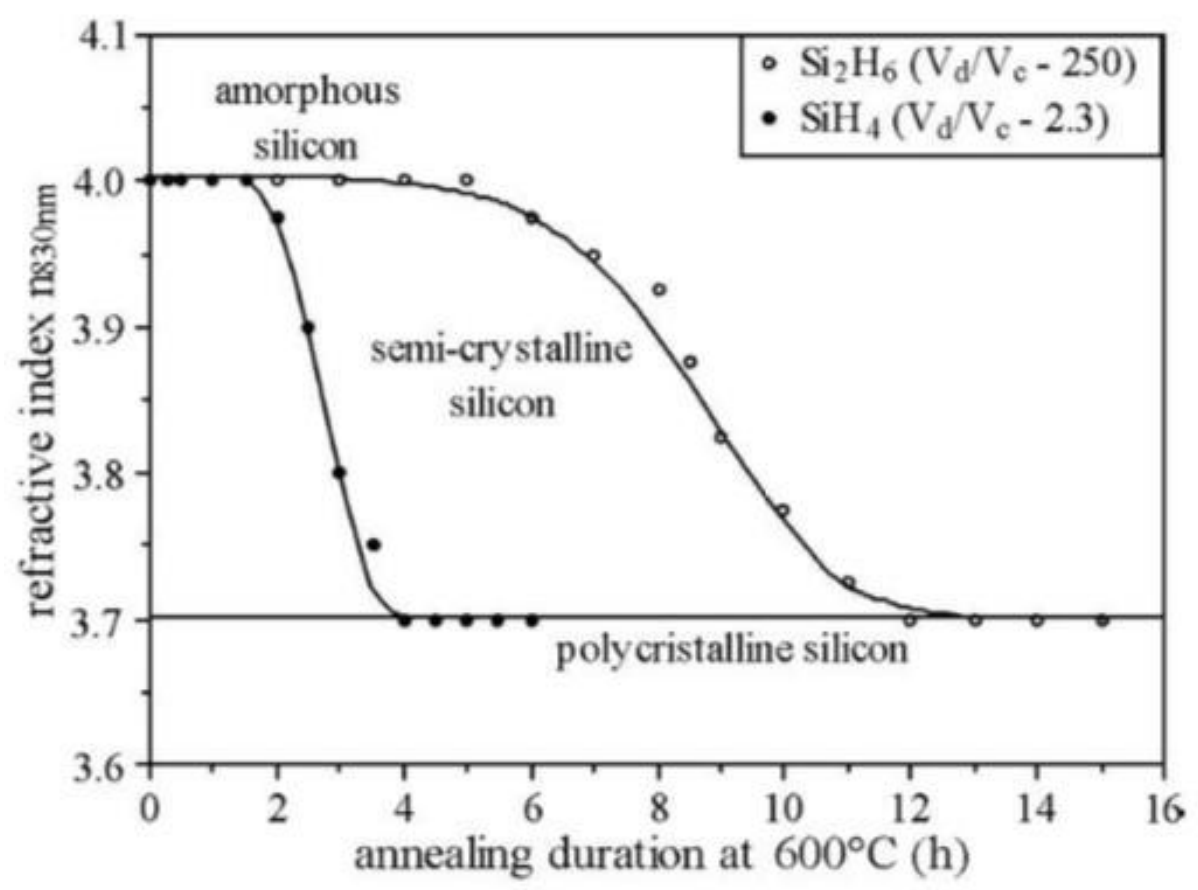

Figure 3: Refractive index variation with annealing duration for amorphous silicon films deposited from silane $\mathrm{SiH}_{4}$ and disilane $\mathrm{Si}_{2} \mathrm{H}_{6}$ gaseous sources 
silane $\mathrm{SiH}_{4}$
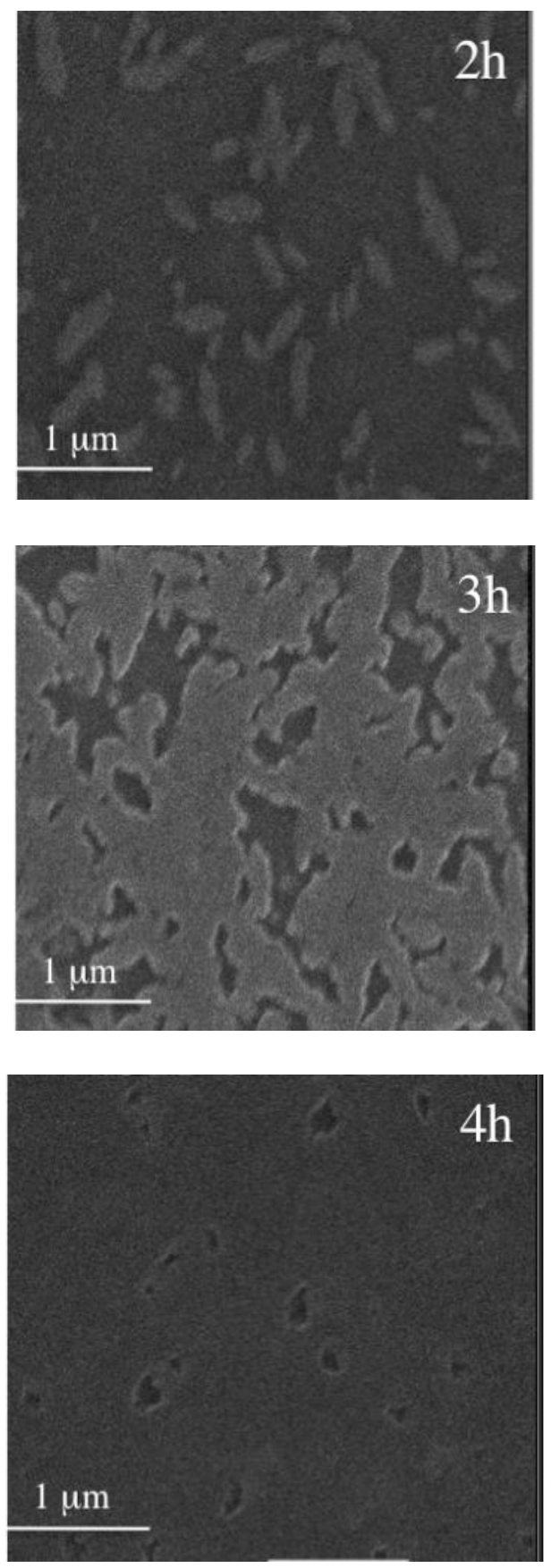

disilane $\mathrm{Si}_{2} \mathrm{H}_{6}$
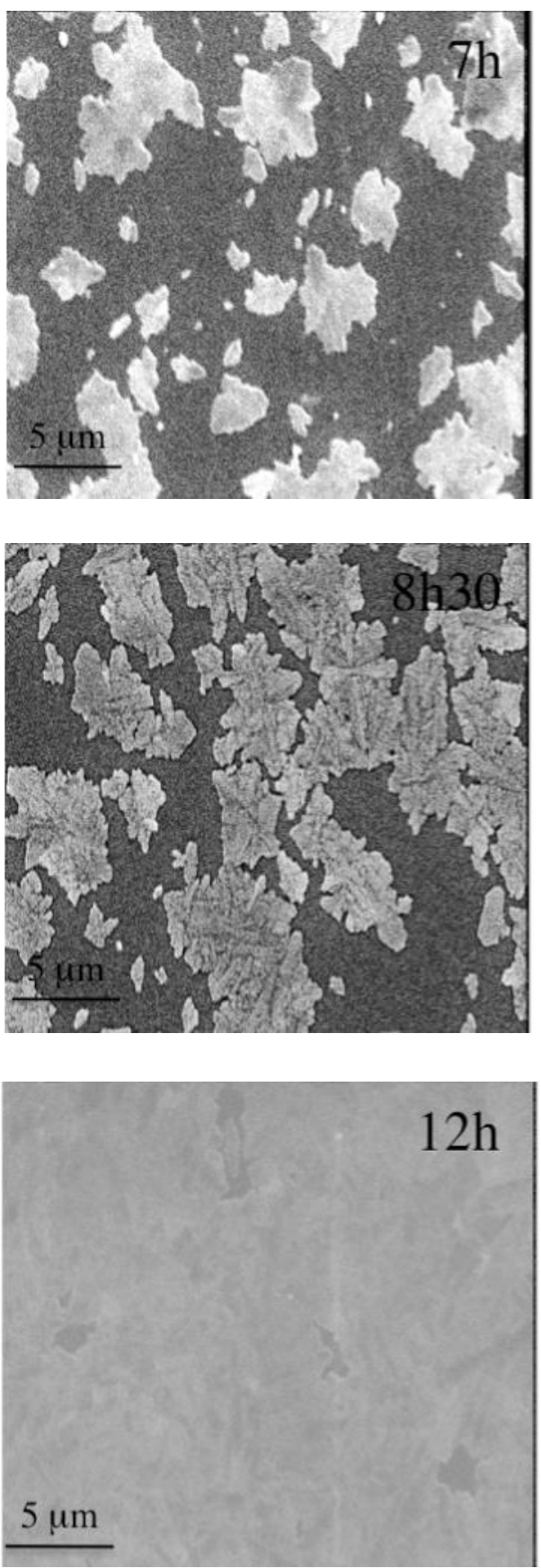

Figure 4: Microstructures of silicon films for different annealing durations at $600^{\circ} \mathrm{C}$ for the silane $\mathrm{SiH}_{4}$ and disilane $\mathrm{Si}_{2} \mathrm{H}_{6}$ gaseous sources 


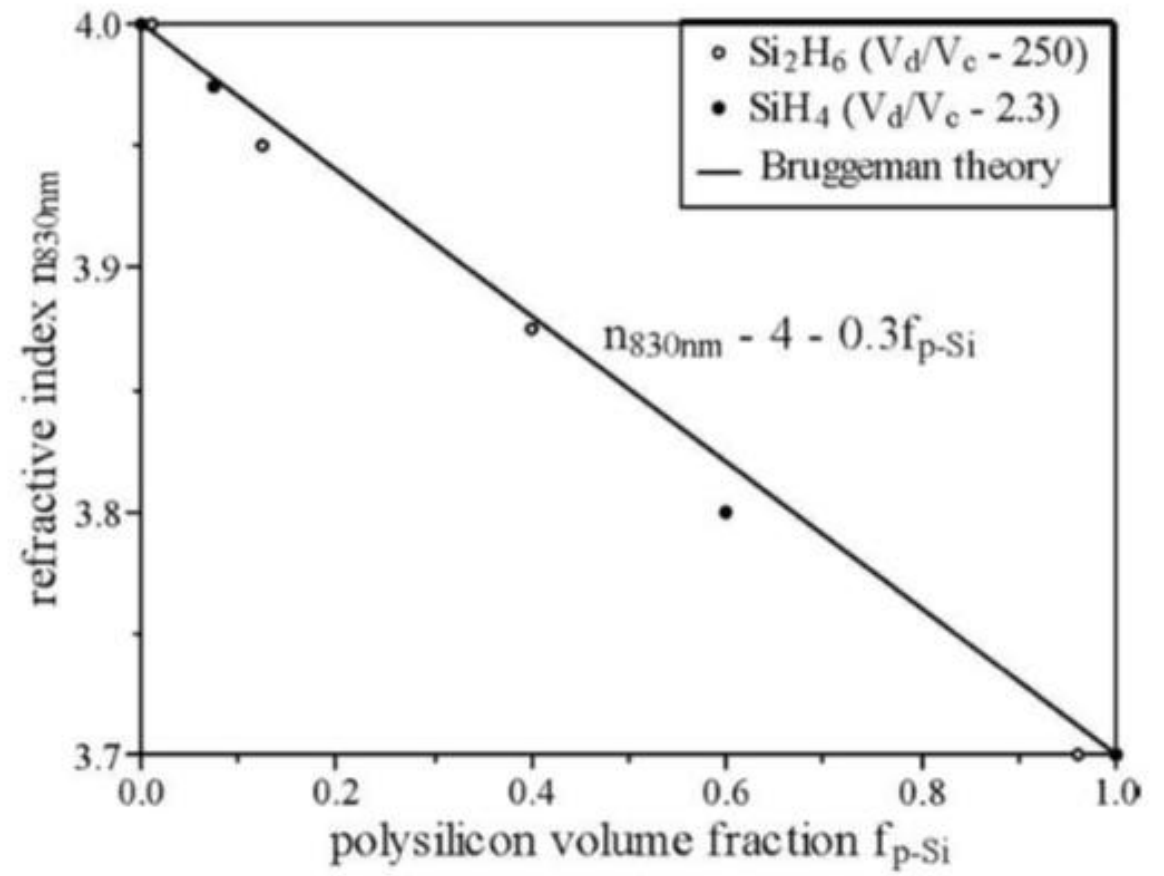

Figure 5: Refractive index n830nm versus polysilicon volume fraction $\mathrm{f}_{\mathrm{p}-\mathrm{Si}}$ 


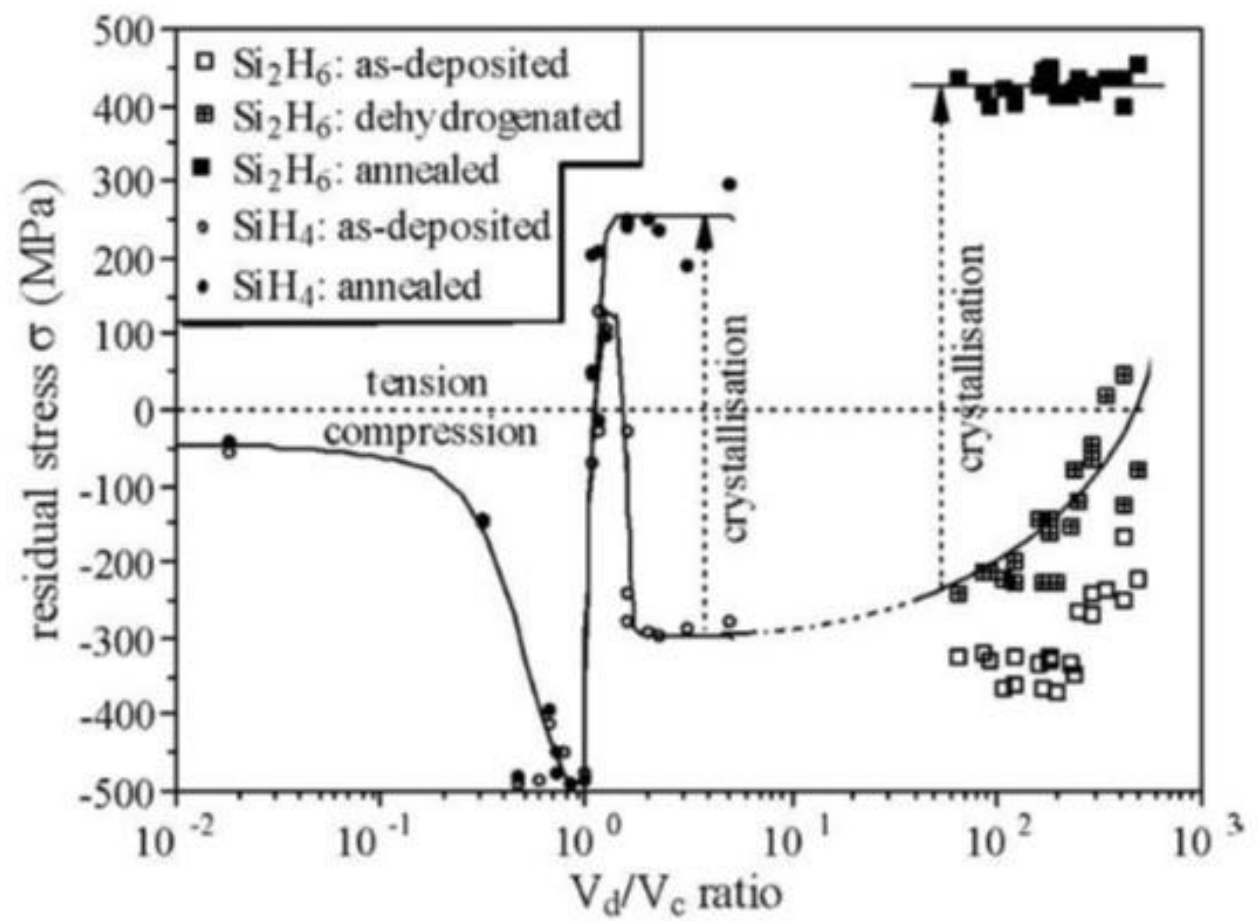

Figure 6: Residual stress $\sigma$ versus $\mathrm{V}_{\mathrm{d}} / \mathrm{V}_{\mathrm{c}}$ ratio

for as-deposited, dehydrogenated and annealed silicon films 


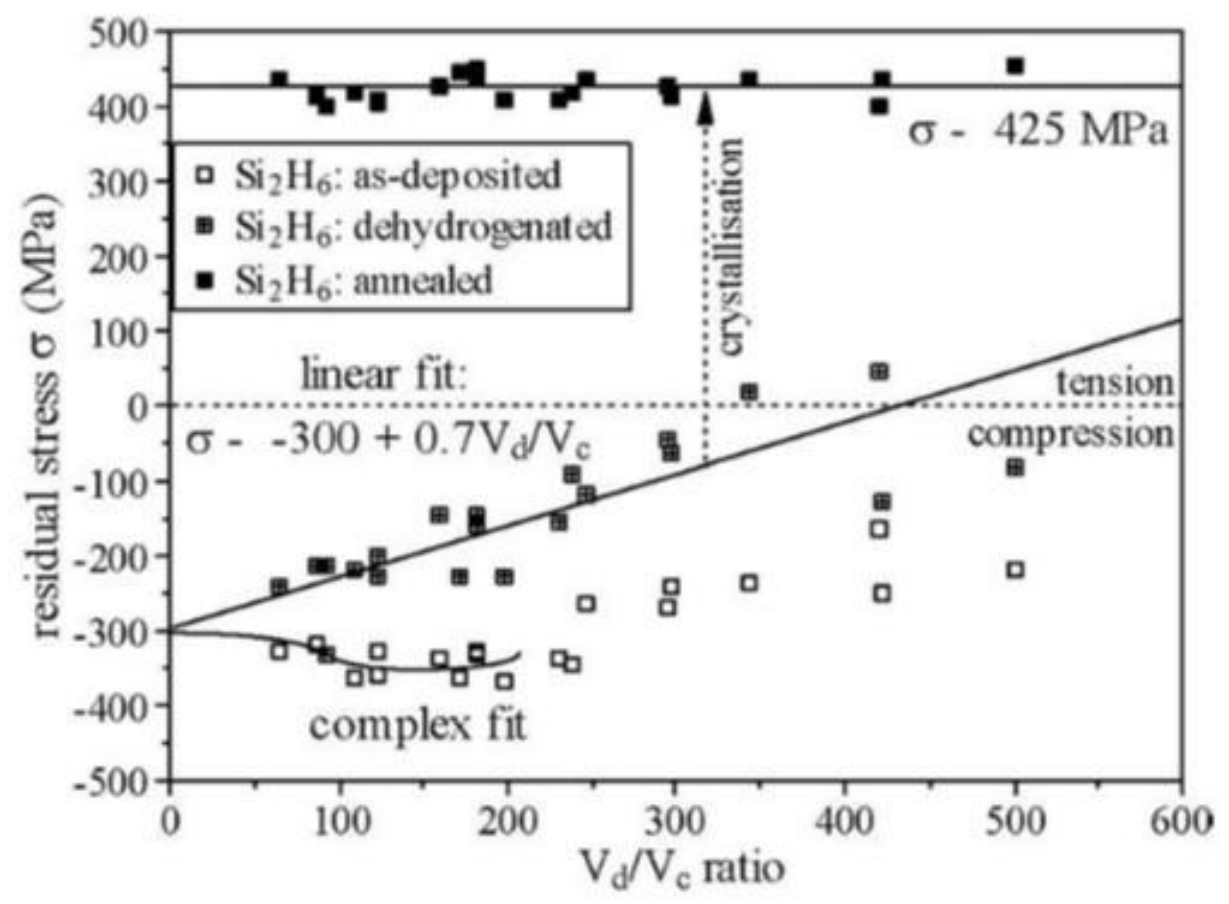

Figure 7: Residual stress $\sigma$ versus $\mathrm{V}_{\mathrm{d}} / \mathrm{V}_{\mathrm{c}}$ ratio

for as-deposited, dehydrogenated and annealed silicon films

(zoom on the disilane $\mathrm{Si}_{2} \mathrm{H}_{6}$ gaseous source) 


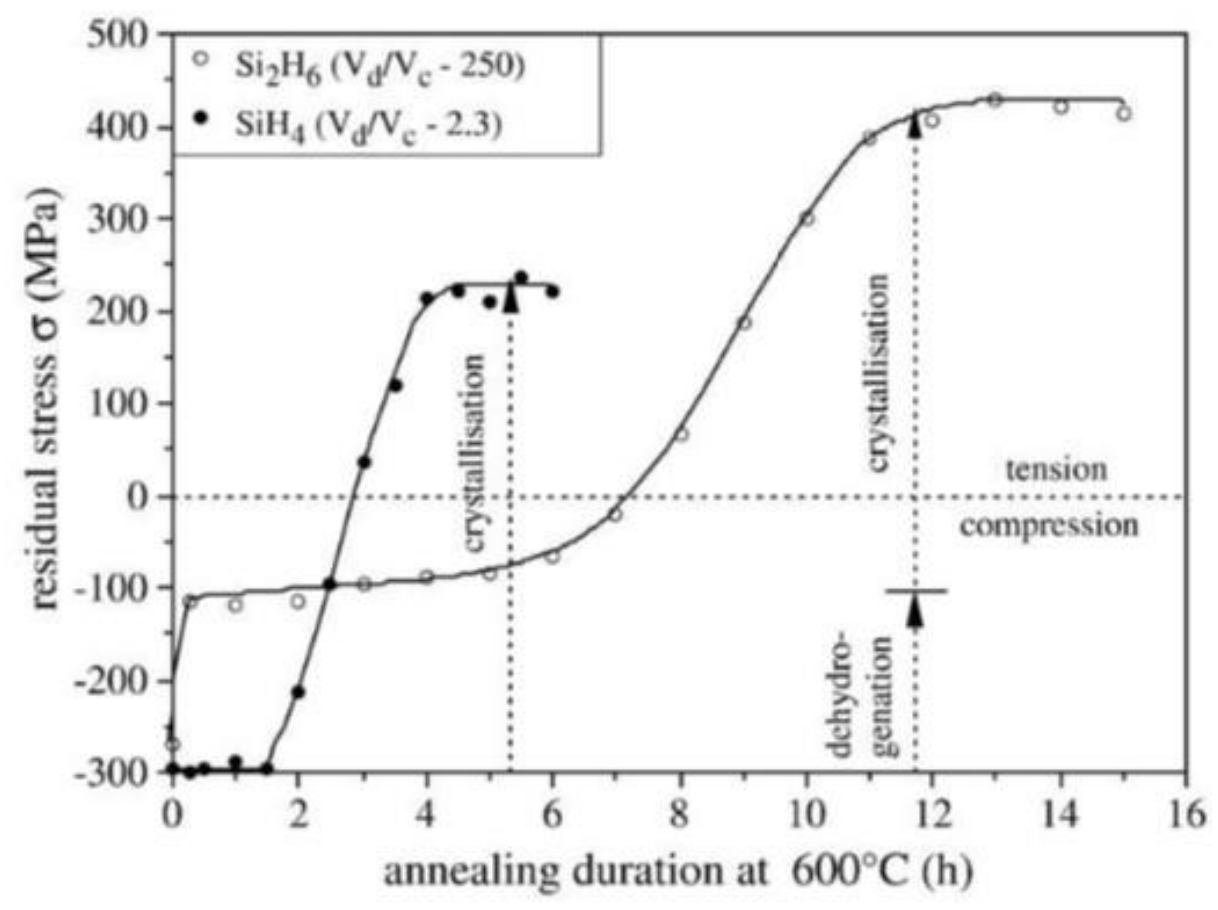

Figure 8: Residual stress index variation with annealing duration for amorphous silicon films deposited from silane $\mathrm{SiH}_{4}$ and disilane $\mathrm{Si}_{2} \mathrm{H}_{6}$ gaseous sources 


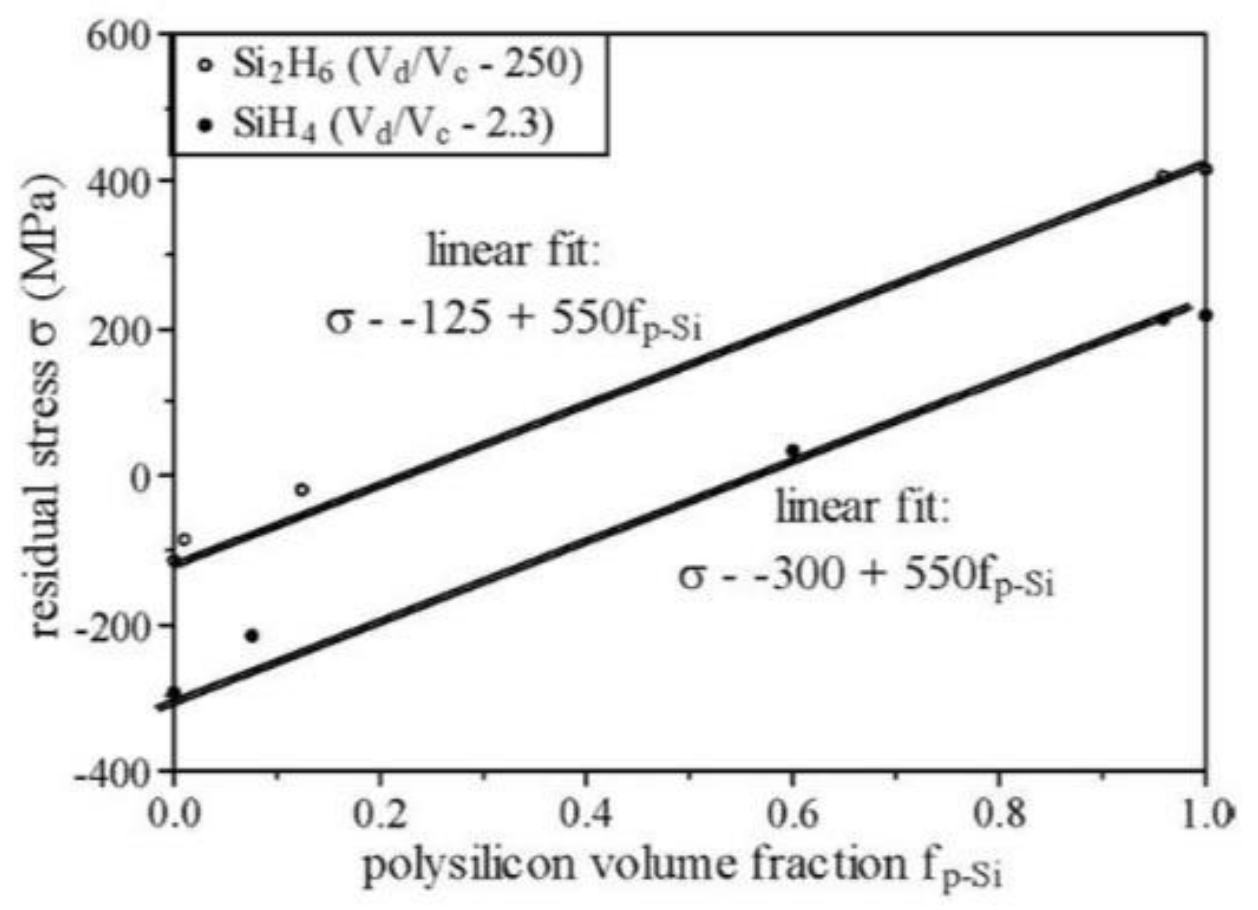

Figure 9: Residual stress $\sigma$ versus polysilicon volume fraction $\mathrm{f}_{\mathrm{p}-\mathrm{Si}}$ 


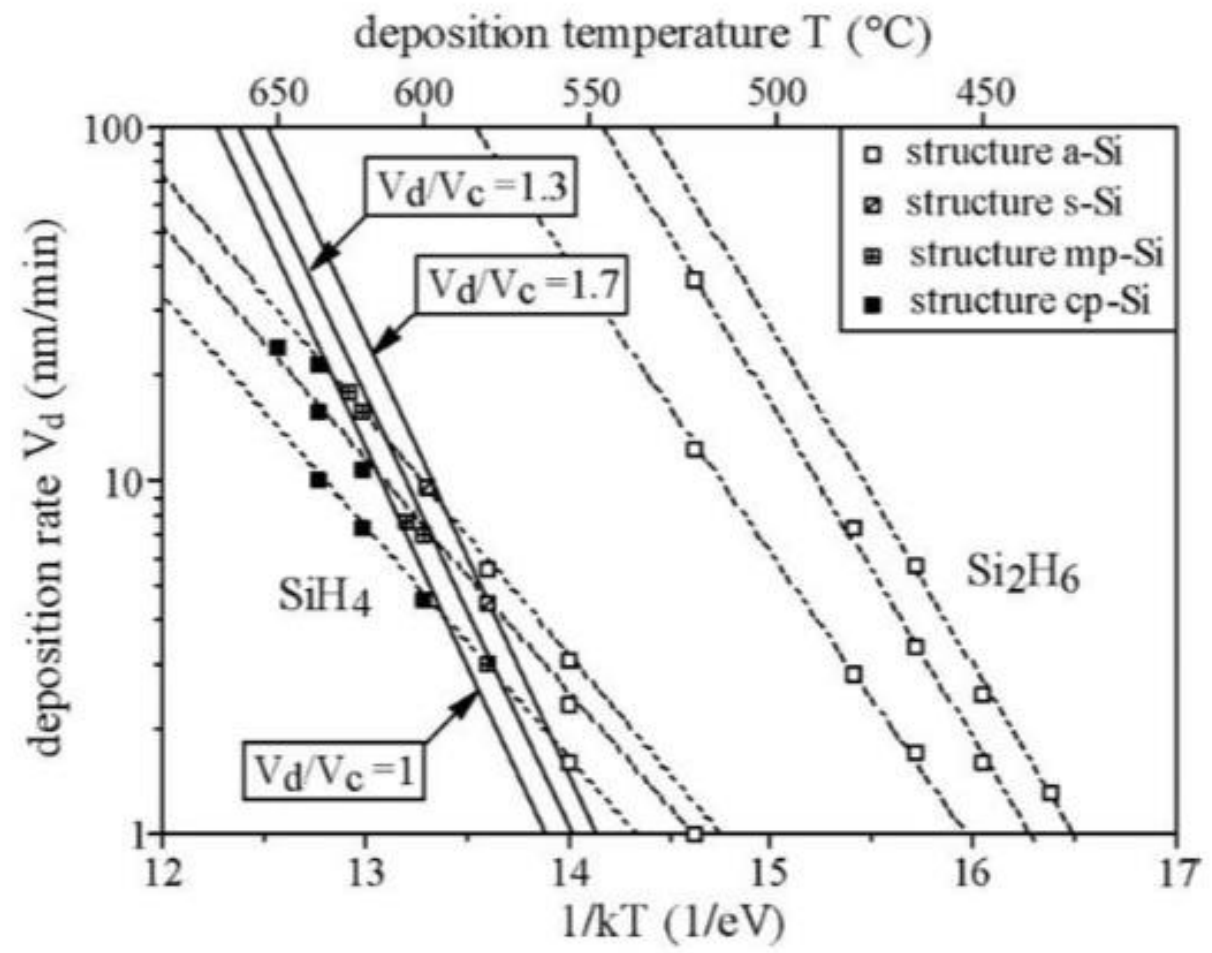

Figure 10: Silicon microstructure versus deposition and crystallization kinetics 